\title{
Mission statement effectiveness: investigating managers' sensemaking role
}

\author{
Seong-Yuen Toh and Shehnaz Tehseen \\ Sunway University, Subang Jaya, Malaysia \\ Ali B. Mahmoud \\ St John's University, New York, New York, USA \\ Jason Cheok \\ Sunway University, Subang Jaya, Malaysia \\ Nicholas Grigoriou \\ Monash University, Victoria, Australia, and \\ John Opute \\ London South Bank University, London, UK
}

Enhanced employee performance levels

\begin{abstract}
Purpose - This study highlights the instrumental role of the mission statement as a tool used by managers to shape value congruence to achieve enhanced employee performance levels.

Design/methodology/approach - A variance-based structural equation modelling was used to analyse the data obtained from a sample of 123 managers working in private organisations in Malaysia.

Findings - The management sensemaking approach is useful in mission statement research. Managers' involvement in clarifying the mission statement to various firm stakeholders, especially employees, is the strongest predictor of value congruency between employees and the firm, leading to improved levels of employee behavioural performance. Managers can influence value congruency through two processes: (1) guiding and shaping employees' values and (2) adapting the mission statement's contents.

Research limitations/implications - Future studies can consider the impact of managerial role modelling on employees' value alignment with the firm in longitudinal studies. Other aspects of alignment offer further research opportunities, for example, $\mathrm{HR}$ policy alignment and alignment of marketing and operation strategies with the mission statement.

Practical implications - Managers should move beyond treating the mission statement as a management tool. Instead, it is a firm philosophy that reflects managers' words and deeds and exemplifies their philosophical ideals. Originality/value - Despite three decades of research into the relationship between the mission statement and performance, the results have been mixed. Therefore, this study adopts a sensemaking approach to research the mission-performance relationship underpinned by the resource-based view (RBV) theory.
\end{abstract}

Keywords Mission statement, Sensemaking, Strategic alignment, Value congruence, Managerial role modelling

Paper type Research paper

\section{Introduction}

Although the literature on the strategic management of human resources is varied and extensive in empirical studies, attempts to measure the strategic contribution of managers "characteristically" concerning the organisation's human capital appear sparse. A mission statement is a formal written statement that captures the firm's fundamental, unique and enduring purpose (Alegre et al., 2018). It usually contains three parts: a statement about the firm's current purpose, a statement about its desired future state and the strong values (Braun et al., 2012; Breznik and Law Kris, 2019; Collis and Michael, 2008). Synonymous to the mission statement are terms like "vision", "core ideology", "corporate philosophy", "credo" and "our story" (Stallworth Williams, 2008). The mission statement targets all firm
Received 12 March 2021 Revised 31 July 2021 Accepted 5 September 2021
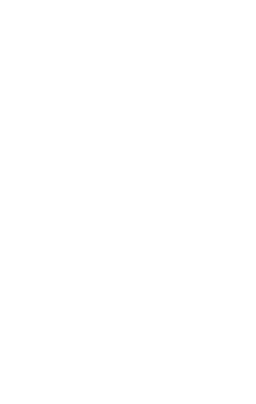
stakeholders (Grünig and Kühn, 2015). Stakeholders include employees, customers, shareholders, the community and the country and its government (Pearce and David, 1987; Amato and Amato, 2002). It is widely held that the mission statement is the "critical starting point for almost every major strategic initiative" (Bartkus and Glassman, 2008). It provides a strategic framework for allocating organisational resources (Bartkus et al., 2000), a sense of purpose, direction (Collins and Porras, 1996) and a sense of mission (Campbell and Yeung, 1991). It further serves as an essential communication tool for internal and external stakeholders (Bartkus et al., 2000). These views underscore the mission statement's importance as a widely adopted management tool (Rigby and Bilodeau, 2011). However, whether the mission statement effectively achieves what researchers claim is challenged by researchers (Salehi-Kordabadi et al., 2020). Evidence on the mission-performance relationship has thus far been mixed (Alegre et al., 2018) and even contradictory (Desmidt et al., 2011). This study posits the premise that the mission statement, when correctly used, is a management strategic effective (Mullane John, 2002). Further, the mission statement's correct use is more viable through the sensemaking approach, through which managers' roles in the strategic alignment and role modelling can bridge the mission-performance research gap.

\section{The strategic link between mission statements and organisational behaviour}

Corporate mission statements are effective when organisational leaders clearly communicate them to staff (Greenberg and Baron, 1997). Mission statements act as carriers of culture, ideology and ethos (Swales and Rogers, 1995). From a corporate culture perspective, the managerial literature focuses on the notion of culture as "a set of norms and values that are widely shared and strongly held throughout the organisation" (O'reilly and Chatman, 1996, p. 166). To advance this definition further and in line with the aims of this study, Patel et al. (2015) found significant evidence that mission statements have a significant positive relationship with organisational performance. Therefore, and to some extent, the mission acts as cultural "glue" that permits an organisation to work as a collective unity (Alegre et al., 2018) to achieve successful organisation performance (Hirota et al., 2010) through employee behaviour (Bart Baetz and Mark, 1998; Lin, 2012).

\section{The Malaysian context}

Malaysia provides fertile ground as the focal location of this study to achieve developed nation status. First, Malaysia must promote economic development to private enterprises. In Malaysia, small to medium enterprises (SMEs) contribute $40 \%$ to Malaysia's economic transformation process (Tahir et al., 2018) and make up 95\% of the total businesses in the country. However, research on leadership in Malaysia is not as extensive as in Western contexts. Despite efforts by scholars to develop an understanding of leadership practices in Malaysia, a review of the literature reveals that minimal effort has been made to examine leaders concerning the leadership behaviour adopted in SMEs (Mohd Sam et al., 2012; Hashim and Zakaria, 2013). Leadership style is how a leader provides direction to his/her team to execute their tasks, how the leader motivates their subordinates and how the leader communicates and relates to their staff people (Gharibvand, 2012). This conceptualisation is fundamental in Malaysia; a multi-ethnic society comprises $65 \%$ indigenous Malays, $25 \%$ Chinese and 7\% Indians and 3\% of other minor ethnic groups (Haque, 2003). These findings suggest that with such a diverse ethnic workforce, directing employees towards a certain behaviour (e.g. working towards organisational performance goals according to the firm's mission statement) may provide challenges for business leaders (Minai et al., 2012). Since a firm's staff members are an organisational resource employed to achieve organisational objectives and contribute to firm performance, we use a resource-based view (RBV) of the firm to further advance our understanding of the effectiveness of mission statements. 
An Eastern perspective of mission statements

Given the diversity of leadership styles across different cultures, we expect to find firms from different national cultures placing a different emphasis in their mission statements suggesting different organisational approaches to achieving organisational performance. For instance, in a study of leading universities' mission statements, Bayrak (2020) found that European universities were more likely to use "research" in the wording of their mission statements than universities from Asia. Conversely, Asian based universities used "technology" in their mission statements more often than Western universities. Interestingly, both Eastern and Western universities frequently used "leader" or "leadership". In a similar study to that of Bayrak (2020), Ahman (2020) found that "becoming", "pre-eminent" and "technology" were among the most popular words used in vision statements in Indonesian universities. These findings indicate the emphasis placed by Eastern universities to guide their strategic direction.

\section{Theoretical framework}

The RBV of firms is the focal lens used in this study. The theoretical framework in this study is shown in Figure 1. Generally, RBV recognises strategic alignment forms as a source of competitive advantage (Schroeder et al., 1986; Amit and Belcourt, 1999; Hung, 2006; Sardana et al., 2016). The mission statement is the primary reference of espoused values in the firm. Thus, the strategic alignment of values is a source of competitive advantage (Barney and Clark, 2007). Based on the RBV, mission statement clarity in various aspects of the three components of purpose, vision and values can facilitate strategic alignment of values (Lahey and Nelson, 2020), contributing to the firm's competitive advantage.

\section{Mission statement clarity and employee behavioural performance}

Previous research shows that the mission statement's clarity is likely to influence employee behaviour (Campbell, 1989; Campbell and Yeung, 1991; Alegre et al., 2018). When the firm's

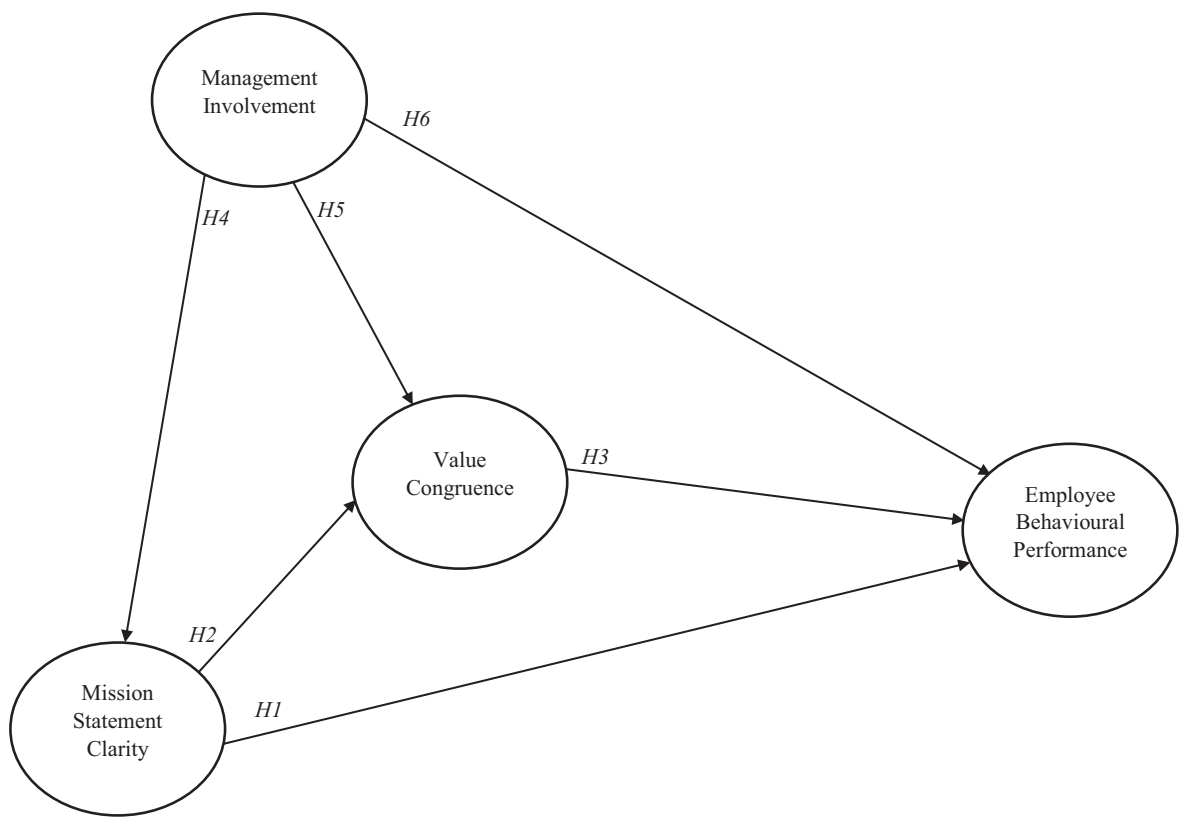

Enhanced employee performance levels

\author{
然
}


mission statement clearly states its strategic objectives, its employees behave in a manner congruent towards achieving those objectives (Yilmaz and Ergun, 2008). Moreover, Bart (1997) identifies a lack of clarity in the mission statement as a likely reason why firms fail to achieve success. Similarly, Sattari et al. (2011) state that clarity of the mission statement regarding readability and understanding is vital for comprehension. They argued that only a straightforward and understandable mission statement would have "a chance of achieving the desired positive outcomes" (p. 282). Therefore, we posit.

H1. Mission statement clarity is positively related to employee behavioural performance.

\begin{abstract}
Mission statement clarity affects value congruence
The concept of value congruence captures the essence of the strategic alignment of values in the firm. A firm has an influential culture when there is a high degree of value congruence between employees and the firm (Meglino et al., 1989; O'reilly et al., 1991; Kotter and Heskett, 2008; Posner, 2010). Employees are attracted to organisations that have values that fit with their own. The mission statement can promote such high-value congruence. This is because it can act as "the gel that binds organisations together", inspiring employees (Ireland and Hirc, 1992) and promoting shared values, providing a standard of behaviour and improving commitment (Campbell and Yeung, 1991; Campbell et al., 1992; Bart, 1997; Alegre et al., 2018). Based on this empirical evidence, when a firm's mission statement is clear about its purpose, like-minded people tend to be attracted to it.
\end{abstract}

H2. Mission statement clarity is positively related to value congruence.

\title{
Value congruence affects employee behavioural performance
}

Studies have shown that firms with high-value congruence experience a positive behavioural change in their employees (Denisi and Smith, 2014). Posner et al. (1985) find that value congruence is positively related to managers' ethical behaviour. Furthermore, Edwards and Cable (2009) confirm that increasing value congruence improves employee attitudes and behaviours. People with high shared values tend to think similarly (Gardner et al., 2009), behave similarly (Cameron and Quinn, 2011) and have similar attitudes (Meglino et al., 1989). In line with previous research, we propose.

H3. Value congruence is positively related to employee behavioural performance.

\section{Management involvement in sensemaking}

Management involvement in sensemaking engages with employees in the firm where perception and meaning are shaped and aligned (Thiry, 2001; Ancona, 2012; Marshall, 2018). Less is made of this type of managerial sensemaking in clarifying the meaning of the mission statement and shaping the values and behaviours of employees. The adoption of this approach in studying the mission statement should prove fruitful given that effectiveness of management sensemaking in shaping value congruence is supported by research (Maitlis, 2005; Rolls et al., 2008; Hoffman et al., 2011). In mission statement research, management involvement is defined as the management's involvement in implementing the mission statement for strategic alignment and strengthening organisational culture (Ralph et al., 2014; Toh and Koon, 2017). Since mission statements are expected to evolve in tandem with the external environment (Koch et al., 2014), managers are expected to lead this adaptation process.

First, the connection between clarification of mission statements and management participation is recognised in previous research (e.g. Senge, 1997; Collins and Porras, 2005; Kouzes and Posner, 2006; Dumitrascu and Feleaga, 2019) and validated recently (Rupprecht 
et al., 2013). Second, in clarifying the values of the firm, the involvement of management has also been acknowledged. For example, managers send a strong signal to others when directly involved in implementing the mission statement (Mullane John, 2002). Senior management pays attention to, measures and controls how they influence others and embed beliefs, assumptions and values into their organisational culture (Ralph et al., 2014). Furthermore, managers adopt the mission statement to be consistent with internal members' values (Seeber et al., 2019). Third, in role modelling behaviours, managers set examples by their own behaviours for others to follow. This role modelling has been stressed in the academic literature (Hermalin, 1998), business studies (Kouzes and Posner, 2006), military scholarship (Keegan, 2011) and popular self-help books (Maxwell, 2007). By "deliberate role modelling, teaching, and coaching" (Schein, 2010), managers can influence others. Based on this evidence, the following three hypotheses are deduced:

H4. Management involvement is positively related to mission statement clarity.

H5. Management involvement is positively related to value congruence.

H6. Management involvement is positively related to employee behavioural performance.

\section{Enhanced employee performance levels}

\section{Methods}

Measurements of constructs were adopted from established studies. We used measures developed by Bart Christopher et al. (2001) to measure mission statement clarity O'reilly and Chatman (1986) and Cable and Derue (2002) to measure value congruence, Bart Baetz and Mark (1998), Desmidt and Heene (2003) and Desmidt et al. (2011) to measure employee behavioural performance and Posner et al. (1985), Bart Baetz and Mark (1998) and Nowlin (2009) to measure management involvement. Face validity of the instrument was ensured by consulting three independent subject matter experts over the measuring items wording, validity and relevance in three separate face-to-face interviews, with each lasting $90 \mathrm{~min}$ on average. The improved survey instrument was also tested to confirm that the reliability requirement $(>0.70)$ was met before data collection. A purposive sampling technique was employed to approach participants who were MBA students and held managerial roles in private sector organisations. Specifically, the participants would have more than two years of working experience accompanied with line management responsibilities. The final survey was self-administered through paper-and-pencil questionnaires as well as online. In addition to that, convenience sampling was conducted through social media and using an online version of the survey to solicit potential respondents who were managers who helped snowball sample more participants who were managers. G*power analysis (Faul et al., 2007) was used to determine the minimum sample size of 76 based on the statistical power of 0.8 when a 3-predictor variable equation was used as a baseline. The survey was concluded with 123 completed responses, thus exceeding the minimum threshold.

\section{Results \\ Data}

Our study took place in Malaysia in 2018. It drew on a sample consisting of managers working in various organisations, covering various industrial sectors and organisational characteristics that would allow us to improve the sample's representative nature and enhance our results' external validity. The participants were approached through their HR departments, and the data were collected using an online survey. A hundred twenty-three responses were returned and used in data analysis. Our sample had an even spread of male $(52 \%)$ and female ( $48 \%)$ managers with an overall average age of 34 . More than half $(59.3 \%)$ had up to 10 staff reporting to them. Almost all (above $98 \%$ ) had a bachelor's degree or higher, 
and more than half held middle and senior management positions (60.9\%). Most of the respondents $(66 \%)$ had worked in their respective companies for 2-10 years.

\section{Common method variance analysis}

Common method variance (CMV) is a critical issue for any study when data are gathered for all variables from the same respondents' types (Tehseen et al., 2017). To detect this problem, we used two statistical methods, including the correlation matrix approach maximum collinearity assessment method proposed by Bagozzi et al. (1991) and Kock (2015), respectively. Inter-correlations were found less than 0.90 using a correlation matrix approach, negating the CMV as a concern. Likewise, in the maximum collinearity assessment method, all constructs' (variance inflation factor) VIF values were $<3.3$, suggesting no significant concerns for CMV.

These studies showed that this study's findings would be very reliable to draw meaningful implications due to non-significant CMV concerns. Since the PLS-SEM techniques are ideal for non-normal data sets (Mahmoud et al., 2021b, c); thus, multivariate kurtosis and skewness were examined using the WebPower software (Webpower, 2015). Results revealed that data were not multivariate normal because of Mardia's multivariate skewness of 6.27 and kurtosis of 32.92. We used Smart PLS to analyse the data, which is ideal for analysing non-parametric data. The measurement and structural models were evaluated using Smart after conducting the CMV and non-parametric tests. The proposed steps by Hair et al. (2019) were followed in testing measurement and structural model assessments.

\section{Evaluation of measurement model}

The measurement model's evaluation includes analysing factor loadings, the reliability of variables, convergent and discriminating validities (Ringle et al., 2020). First, variables' reliability was measured, examining indicators' reliability and composite reliability (Hair et al., 2017). The measurement model's findings show the acceptable values of both the reliabilities, i.e. composite reliability and Cronbach's alpha (Hair et al., 2017). Additionally, the rho A value was also appropriate. The variables' convergent validity was also tested by evaluating the outer loading values and average variance extracted values (AVE) (Hair et al., 2017). The reliability and convergent validity scores for all of the constructs were above the respective threshold values of 0.70 and 0.50 , as shown in Table 1.

Following the suggestion by Henseler et al. (2016) for the analysis of discriminant validity, this study used HTMT to measure similarity between latent variables. The discriminating validity evaluation aims to ensure that a reflective construct in the PLS path model has the best relationship with its own indicators concerning any other construct (Hair et al., 2017). HTMT scores $<0.90$ suggest that discriminating validity is established between two reflective constructs. Table 2 shows that the model's discriminant validity is well established because of the low HTMT value of 0.90 .

\section{Evaluation of structural model}

The structural model was examined according to the recommendations of Hair et al. (2019). The values of $\beta$ and $t$-values, $f^{2}$, VIF, $R^{2}$ and $Q^{2}$, were analysed. To assess the structural model's collinearity problems, the VIF were evaluated. The VIF value of less than 5 indicates no collinearity issue among latent variables (Hair et al., 2017). Likewise, the $\beta$ values more than 0.2 usually give significant $t$-values. Table 3 illustrates the findings of the proposed hypotheses. H1 was not supported because of the non-significant $t$ value for the relationship between mission statement clarity and employee behavioural performance $\beta=0.088$, 


\begin{tabular}{|c|c|c|c|c|c|c|c|}
\hline Constructs & Items & Loadings & $\begin{array}{c}\text { Cronbach's } \\
\text { alpha }\end{array}$ & rho_A & $\begin{array}{l}\text { Composite } \\
\text { reliability }\end{array}$ & $\begin{array}{l}\text { Average variance } \\
\text { extracted (AVE) }\end{array}$ & $\begin{array}{l}\text { Enhanced } \\
\text { employee }\end{array}$ \\
\hline \multirow{9}{*}{$\begin{array}{l}\text { Employee } \\
\text { behavioural } \\
\text { performance }\end{array}$} & EBP1 & 0.847 & \multirow[t]{9}{*}{0.948} & \multirow[t]{9}{*}{0.95} & \multirow[t]{9}{*}{0.956} & \multirow[t]{9}{*}{0.707} & leve \\
\hline & EBP2 & 0.872 & & & & & \\
\hline & EBP3 & 0.825 & & & & & \\
\hline & EBP4 & 0.831 & & & & & \\
\hline & EBP5 & 0.813 & & & & & \\
\hline & EBP6 & 0.850 & & & & & \\
\hline & EBP7 & 0.789 & & & & & \\
\hline & EBP8 & 0.873 & & & & & \\
\hline & EBP9 & 0.865 & & & & & \\
\hline \multirow{3}{*}{$\begin{array}{l}\text { Management } \\
\text { involvement }\end{array}$} & MI1 & 0.795 & \multirow[t]{3}{*}{0.787} & \multirow[t]{3}{*}{0.794} & \multirow[t]{3}{*}{0.876} & \multirow{3}{*}{0.702} & \\
\hline & MI2 & 0.881 & & & & & \\
\hline & MI3 & 0.836 & & & & & \\
\hline \multirow{5}{*}{$\begin{array}{l}\text { Mission statement } \\
\text { clarity }\end{array}$} & $\mathrm{MSC} 1$ & 0.726 & \multirow[t]{5}{*}{0.792} & \multirow[t]{5}{*}{0.796} & \multirow[t]{5}{*}{0.857} & \multirow[t]{5}{*}{0.547} & \\
\hline & MSC2 & 0.809 & & & & & \\
\hline & $\mathrm{MSC} 3$ & 0.751 & & & & & \\
\hline & $\mathrm{MSC} 4$ & 0.683 & & & & & \\
\hline & MSC5 & 0.722 & & & & & \\
\hline \multirow[t]{4}{*}{ Value congruence } & VC1 & 0.883 & \multirow[t]{4}{*}{0.926} & \multirow[t]{4}{*}{0.929} & \multirow[t]{4}{*}{0.947} & \multirow[t]{4}{*}{0.818} & Table 1. \\
\hline & $\mathrm{VC} 2$ & 0.893 & & & & & Items' loadings, \\
\hline & VC3 & 0.940 & & & & & reliabilities and \\
\hline & $\mathrm{VC} 4$ & 0.902 & & & & & convergent validit \\
\hline
\end{tabular}

$1 \quad 2$

1. Employee behavioural performance

2. Management involvement

3. Mission statement clarity

$0.778(0.692,0.859)$

$0.463(0.307,0.613) \quad 0.500(0.313,0.688)$

4. Value congruence

$0.647(0.532,0.746)$

$0.743(0.631,0.839)$

$0.566(0.420,0.689)$

Table 2. HTMT

\begin{tabular}{|c|c|c|c|c|c|c|c|c|}
\hline Hypothesis & Path & $\beta$ & $t$ & $p$ & LL & UL & Decision & $f^{2}$ \\
\hline H1 & $\begin{array}{l}\text { Mission statement } \\
\text { clarity } \rightarrow \text { employee } \\
\text { behavioural performance }\end{array}$ & 0.088 & 1.334 & 0.091 & -0.025 & 0.191 & $\begin{array}{l}\text { Not } \\
\text { supported }\end{array}$ & 0.012 \\
\hline $\mathrm{H} 2$ & $\begin{array}{l}\text { Mission statement } \\
\text { clarity } \rightarrow \text { value congruence }\end{array}$ & 0.277 & 4.159 & 0.000 & 0.161 & 0.384 & Supported & 0.122 \\
\hline H3 & $\begin{array}{l}\text { Value } \\
\text { congruence } \rightarrow \text { employee } \\
\text { behavioural performance }\end{array}$ & 0.269 & 3.598 & 0.000 & 0.139 & 0.383 & Supported & 0.08 \\
\hline $\mathrm{H} 4$ & $\begin{array}{l}\text { Management } \\
\text { involvement } \rightarrow \text { mission } \\
\text { statement clarity }\end{array}$ & 0.397 & 4.264 & 0.000 & 0.225 & 0.533 & Supported & 0.187 \\
\hline H5 & $\begin{array}{l}\text { Management } \\
\text { involvement } \rightarrow \text { value } \\
\text { congruence }\end{array}$ & 0.526 & 8.393 & 0.000 & 0.417 & 0.622 & Supported & 0.439 \\
\hline $\mathrm{H} 6$ & $\begin{array}{l}\text { Management } \\
\text { involvement } \rightarrow \text { employee } \\
\text { behavioural performance }\end{array}$ & 0.471 & 6.979 & 0.000 & 0.358 & 0.579 & Supported & 0.270 \\
\hline
\end{tabular}

Table 3.

Results of hypothesis testing 
$t=1.334$ ). Conversely, $\mathrm{H} 2$ and $\mathrm{H} 3$ were supported due to the positive and significant relationship between mission statement clarity and value congruence $(\beta=0.277, t=4.159)$ and between value congruence and employee behavioural performance $(\beta=0.269, t=3.598)$. Likewise, H4 regarding the positive and significant relationship between management involvement and mission statement clarity was also supported with a $\beta$ value of 0.397 and $t$ value of 4.264. $\mathrm{H} 5$ and $\mathrm{H} 6$ were also supported due to the significant relationships of management involvement with mission statement clarity $(\beta=0.526, t=8.393)$ and employee behavioural performance $(\beta=0.471, t=6.979)$. The effect sizes $f^{2}$ values were also evaluated after testing the hypotheses to reveal the substantial impact of a specific construct on a particular endogenous construct. According to the guide of Cohen (2013), the effect sizes $f^{2}$ of 0.025 are considered small, whereas the values 0.150 and 0.35 , respectively, indicate medium and high effect sizes. The $f^{2}$ effect sizes of management involvement for employee behavioural performance and mission statement clarity were 0.270 and 0.187 , respectively, indicating their medium-size effects; thus, medium importance for these constructs. At the same time, the $f^{2}$ effect size of management involvement was 0.439 for value congruence showing a large effect size, thus, considerable importance. On the other hand, the $f^{2}$ effect size of mission statement clarity for employee behavioural performance and value congruence was found at 0.012 and 0.122 , respectively, showing its small size effects, and thus, little importance for these constructs. Similarly, the $f^{2}$ effect size of value congruence for employee behavioural performance was 0.08 indicating a small effect size and little importance for this construct.

Regarding the indirect effects (see Table 4), value congruence was found to positively and significantly mediate the relationship between mission statement clarity and employee behavioural performance $(B=0.075, \mathrm{SE}=0.028, t=2.712)$ and between management involvement and employee behavioural performance $(B=0.142$, SE $=0.044, t=3.207)$. However, the indirect effect of mission statement clarity on employee behavioural performance through management involvement was found non-significant $(B=0.035$, $\mathrm{SE}=0.03, t=1.157$ ). Moving forward, management involvement was found to indirectly and positively predict employee behavioural performance through the sequence: mission statement clarity $\rightarrow$ value congruence $(B=0.03$, SE $=0.013, t=2.225)$. Finally, mission statement clarity positively and significantly mediated the relationship between management involvement and value congruence $(B=0.11, \mathrm{SE}=0.028, t=2.986)$. Figure 2 shows the hypothesis testing results.

Table 4.

\begin{tabular}{lccccccc}
\hline Path & $B$ & SE & $t$ & $p$ & LL & UL & Decision \\
\hline $\begin{array}{l}\text { Mission statement clarity } \rightarrow \text { value } \\
\text { congruence } \rightarrow \text { employee behavioural } \\
\text { performance }\end{array}$ & 0.075 & 0.028 & 2.712 & 0.003 & 0.035 & 0.125 & Supported \\
$\begin{array}{l}\text { Management involvement } \rightarrow \text { value } \\
\text { congruence } \rightarrow \text { employee behavioural } \\
\text { performance }\end{array}$ & 0.142 & 0.044 & 3.207 & 0.001 & 0.073 & 0.217 & Supported \\
$\begin{array}{l}\text { Management involvement } \rightarrow \text { mission } \\
\text { statement clarity } \rightarrow \text { employee behavioural } \\
\text { performance }\end{array}$ & 0.035 & 0.03 & 1.157 & 0.124 & -0.006 & 0.09 & $\begin{array}{l}\text { Not } \\
\text { supported }\end{array}$ \\
$\begin{array}{l}\text { Management involvement } \rightarrow \text { mission } \\
\text { statement clarity } \rightarrow \text { value } \\
\text { congruence } \rightarrow \text { employee behavioural } \\
\text { performance }\end{array}$ & 0.03 & 0.013 & 2.225 & 0.013 & 0.013 & 0.056 & Supported \\
$\begin{array}{l}\text { Management involvement } \rightarrow \text { mission } \\
\text { statement clarity } \rightarrow \text { value congruence }\end{array}$ & 0.11 & 0.037 & 2.986 & 0.001 & 0.057 & 0.175 & Supported \\
\hline
\end{tabular}




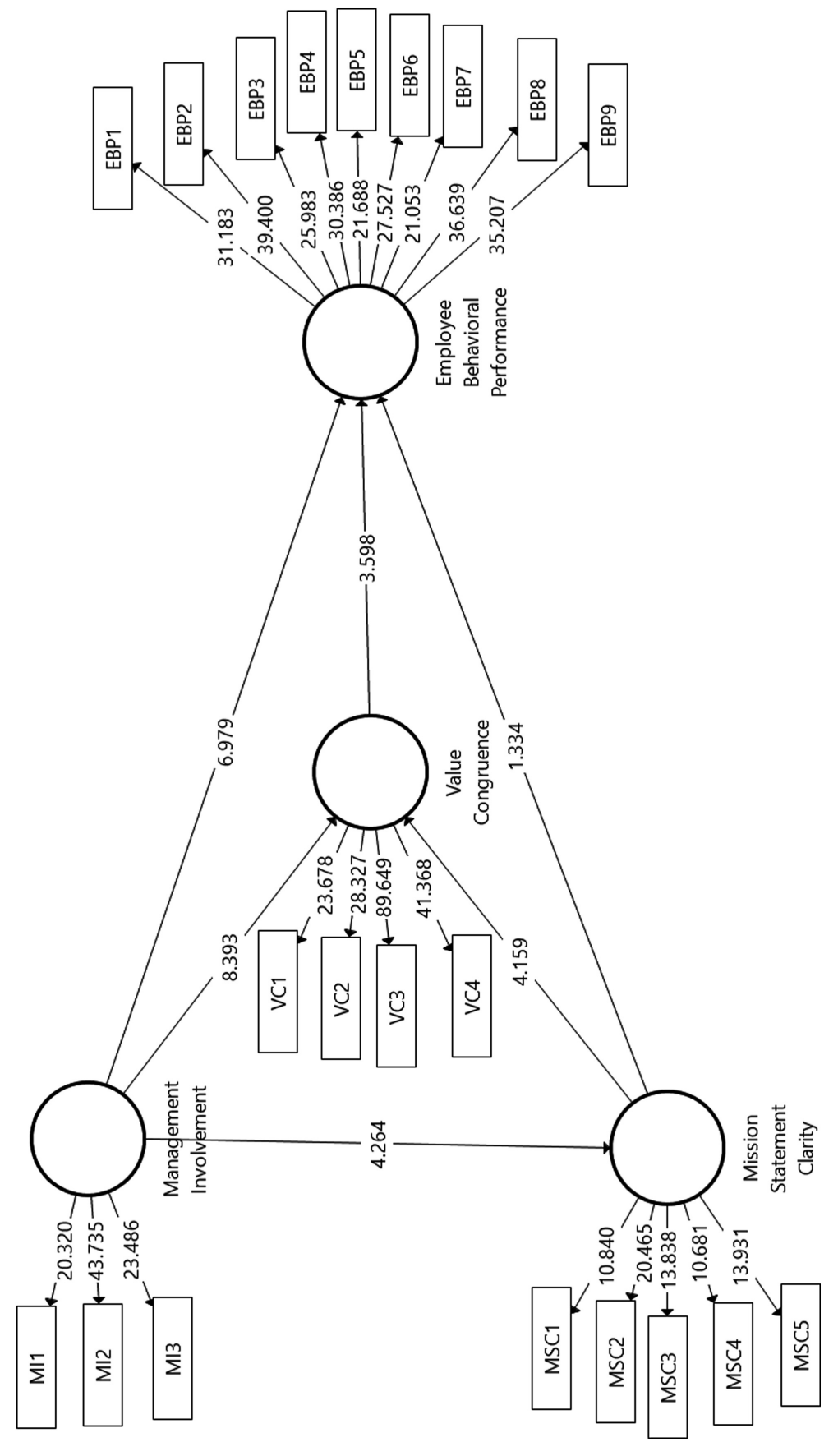

Enhanced employee performance levels

Figure 2. Structure model evaluation 
The model's predictive accuracy determined by the coefficient of determination ( $R^{2}$ value) was also examined. This coefficient of determination reflects the combined influence of all exogenous constructs. Cohen (2013) suggests the $R^{2}$ value of higher than 0 is always acceptable. Thus, since the $R^{2}$ values of employee behavioural performance (0.519), mission statement clarity (0.157) and value congruence $(0.469)$ were above 0 ; therefore, our model is adequate predictive accuracy.

Eventually, blindfolding is a form of sample reuse. It allows measurement of StoneGeisser's $Q^{2}$ value, which represents an evaluation criterion for the cross-validated predictive relevance of the PLS path model (Hair et al., 2017). The $Q^{2}$ values of employee behavioural performance and value congruence were found as 0.335 and 0.357 , respectively, indicating substantial predictive relevance of these constructs. Likewise, the $Q^{2}$ value of mission statement clarity was 0.079 showing medium predictive relevance for this variable. Since these $Q^{2}$ values were above 0 , an excellent relevance for endogenous constructs was concluded. PLS analysis was also used to examine the predictive validity according to the proposed guide of Shmueli et al. (2019). Similarly, $Q^{2}$ values exceeding 0 of the respective predictors suggesting sufficient predictive evidence. As shown in Table 5, most of the PLS (root mean square error estimation (RMSE), MAE and MAPE values were lower than respective LM values; hence, the PLS and LM $Q^{2}$ values were found above 0 that also show ample predictive evidence.

\section{Discussion}

The results of our study demonstrate the instrumental role of the mission statement as a tool used by managers in shaping value congruence to achieve enhanced employee performance levels. The statistical significance of the direct and indirect effects offers strong evidence for the sensemaking approach. The management sensemaking approach in this study involves studying managers' roles in their interactions with employees for the strategic alignment of values and role modelling of behaviours. Alegre et al. (2018) stress the need for micro-level research into the mission statement focussing on how it affects employee beliefs and behaviours. Both the model predictive accuracy and variable predictive relevance show that the management sensemaking approach is an essential endeavour in mission statement research for the firm level.

Furthermore, the results for H4 and H5 support the assumption that managers' involvement in clarifying the mission statement to various stakeholders of the firm, especially employees, is the strongest predictor of value congruency between employees and the firm, leading to improved levels of employee behavioural performance, as indicated by the finding for H3. This is not surprising as it has been suggested that a manager's influence on value congruency can be achieved through two processes. On the one hand (H5), it can be achieved through guiding and shaping employees' values by managers (Schein, 2010). On the other hand, our indirect effects testing shows that managers can adapt or modify the mission statement's value contents (Seeber et al., 2019) to achieve a better fit. It is clear from the results that the first process's predictive power is much stronger than the second. This is consistent with studies that show the importance of the emotional bond in value congruence in mission statement research (Campbell et al., 1992; Campbell and Yeung, 1991). Achieving value congruency is crucial because it is instrumental in predicting performance. While our results suggest that managers should not use the mission statement as a blunt tool, they further emphasise the need for building connections with employees instead.

Finally, the result for $\mathrm{H} 2$ shows that the mission statement by itself does have some independent utility internally as it is instrumental in predicting value congruence. Indirect effects testing suggests that it has a small indirect effect on employee behavioural performance through value congruence. This demonstrates that the mission statement's 
effects mediate the strategic alignment of values on employee behavioural performance. However, Hypothesis 1 shows that the mission statement is not a magic wand and, on its own, will affect firm performance. Managerial intervention is needed to render the mission statement more efficacious.

\section{Practical implications}

This study suggests that managers should move beyond treating the mission statement as merely a management tool for strategic alignment. Instead, managers should utilise the mission statement as a living, communicative tool, a document that reflects managers' words and deeds and exemplifies the firm's philosophical ideals. This is because managers' actions and words are closely scrutinised by others such that any inconsistencies are quickly noticed (Ford et al., 2006). Although deliberate role modelling by managers is vital in this regard, it can be further claimed that the more powerful is the unpremeditated actions as the symbolic influence of inadvertent words and deeds by managers has a lasting impression on employees. Furthermore, such observations get retold and transmitted throughout the firm (and even shared on social media). Thus, we emphasise the importance and existence of a relationship between the human capital of the organisation (particularly the interplay amongst employees), its mission statement and therefore, organisational competitiveness and efficacy. These findings reveal the possibility for further research that links the "character investment" of managers, the mission statement and the organisation's human capital.

The mission statement itself needs to be continuously developed in terms of updating its contents to fine-tune it with changes in the external environment (Koch et al., 2014) while at the same time negotiating a fit with internal stakeholders. This balancing act requires dextrous managers to acquire a repertoire of competencies orientated towards internal change and external alignment (Yukl,2012). Indicative, therefore, is the priority of managerial excellence in multiple aspects, as the conclusion of this study.

In summary, managerial responsibility for communicating an organisation's mission statements to staff, specifically how the mission statement provides the organisation's strategic direction, is an essential predictor of value congruency between a firm and its employees. Further, our finding that the value congruency between the firm and its employees positively affects employee behavioural performance leads us to conclude that clearly enunciated mission statements can affect an employee's performance in achieving the firm's strategic goals.

The findings of the study inform teaching practice in the managerial and organisational behaviour sciences. For instance, classroom scholars may wish to teach the important role of communicating the mission statement to new employees and, more importantly, linking employee performance to the firm's mission. In addition, classroom scholars specialising in communication studies programmes can emphasise how managerial sensemaking affects mission statement effectiveness - for example, sensemaking from a linguistic perspective. Alternatively, sensemaking from a firm's corporate culture perspective.

\section{Limitations and future research}

This study has several limitations. First, a cross-sectional research design was followed. Future studies can consider the impact of managerial role modelling on employees' value alignment with the firm in longitudinal studies, albeit several studies have indicated that longitudinal design's ability over cross-section in detecting causation has been exaggerated (Spector, 2019; Mahmoud et al., 2020, 2021a).

Whilst our study surveyed managers in private sector companies, it is unfortunate that the study did not include questions measuring the business type (e.g. public sector, private 
sector, voluntary sector and SMEs, etc.). Previous research (e.g. Weiss and Piderit, 1999; Jurisch et al., 2013) shows that mission statements are not invariant across different types of organisations. Therefore, we acknowledge not considering the business type in our assessment as a limitation of this study. A future study replicating our model with business type and aim included as independent, control or moderating variables would be very interesting.

This study only focuses on value alignment. Other aspects of alignment offer further research opportunities, for example, HR policy alignment and alignment of marketing and operation strategies with the mission statement. The other limitation of this study is that it has considered only the perspective of managers. Other perspectives, particularly the perspective of employees, should be considered for comparison. Finally, subjective measures of employee behavioural performance were used to determine performance. Future studies should consider objective measures of performance as a comparison.

\section{References}

Ahman, E. (2020), "A content analysis: the vision statements of higher education institutions in Indonesia", Dinasti International Journal of Education Management And Social Science, Vol. 1, pp. 360-367.

Alegre, I., Berbegal-Mirabent, J., Guerrero, A. and Mas-Machuca, M. (2018), "The real mission of the mission statement: a systematic review of the literature", Journal of Management and Organization, Vol. 24, pp. 456-473.

Amato, C.H. and Amato, L.H. (2002), "Corporate commitment to quality of life: evidence from company mission statements", Journal of Marketing Theory and Practice, Vol. 10, pp. 69-87.

Amit, R. and Belcourt, M. (1999), "Human resources management processes: a value-creating source of competitive advantage", European Management Journal, Vol. 17, pp. 174-181.

Ancona, D. (2012), "Sensemaking: framing and acting in the unknown", in Snook, S., Nohria, N. and Khurana, R. (Eds), The Handbook for Teaching Leadership: Knowing, Doing and Being, SAGE Publications, Los Angeles, LA.

Bagozzi, R.P., Yi, Y. and Phillips, L.W. (1991), "Assessing construct validity in organizational research”, Administrative Science Quarterly, Vol. 36, pp. 421-458.

Barney, J.B. and Clark, D.N. (2007), Resource-based Theory: Creating and Sustaining Competitive Advantage, Oxford University Press, Oxford.

Bart, C.K. (1997), "Sex, lies, and mission statements", Business Horizons, Vol. 40, pp. 9-18.

Bart Baetz, C.K. and Mark, C. (1998), "The relationship between mission statements and firm performance: an exploratory study", Journal of Management Studies, Vol. 35, pp. 823-853.

Bart Christopher, K., Bontis, N. and Taggar, S. (2001), "A model of the impact of mission statements on firm performance", Management Decision, Vol. 39, pp. 19-35.

Bartkus, B.R. and Glassman, M. (2008), "Do firms practice what they preach? The relationship between mission statements and stakeholder management", Journal of Business Ethics, Vol. 83, pp. 207-216.

Bartkus, B., Glassman, M. and Bruce Mcafee, R. (2000), "Mission statements: are they smoke and mirrors?”, Business Horizons, Vol. 43, pp. 23-28.

Bayrak, T. (2020), "A content analysis of top-ranked universities' mission statements from five global regions", International Journal of Educational Development, Vol. 72, 102130.

Braun, S., Wesche, J.S., Frey, D., Weisweiler, S. and Peus, C. (2012), "Effectiveness of mission statements in organizations - a review", Journal of Management and Organization, Vol. 18, pp. 430-444.

Breznik, K. and Law Kris, M.Y. (2019), "What do mission statements reveal about the values of top universities in the world?", International Journal of Organizational Analysis, Vol. 27, pp. 1362-1375.
Enhanced

employee

performance

levels

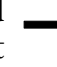


Cable, D.M. and Derue, D.S. (2002), "The convergent and discriminant validity of subjective fit perceptions", Journal of Applied Psychology, Vol. 87, pp. 875-884.

Cameron, K.S. and Quinn, R.E. (2011), Diagnosing and Changing Organizational Culture: Based on the Competing Values Framework, John Wiley \& Sons, San Francisco.

Campbell, A. (1989), "Does your organisation need a mission?", Leadership and Organization Development Journal, Vol. 10, pp. 3-9.

Campbell, A. and Yeung, S. (1991), "Creating a sense of mission”, Long Range Planning, Vol. 24, pp. 10-20.

Campbell, A., Nash, L.L. and Young, D. (1992), A Sense of Mission: Defining Direction for the Large Corporation, Addison Wesley Publishing Company, Boston.

Cohen, J. (2013), Statistical Power Analysis for the Behavioral Sciences, Routledge, New York, NY.

Collins, J.C. and Porras, J.I. (1996), "Building your company's vision", Harvard Business Review, Vol. 74, p. 65.

Collins, J.C. and Porras, J.I. (2005), Built to Last: Successful Habits of Visionary Companies, Random House, London.

Collis, D.J. and Michael, G.R. (2008), "Can you say what your strategy is?”, Harvard Business Review, Vol. 86, pp. 1-9.

Denisi, A. and Smith, C.E. (2014), "Performance appraisal, performance management, and firm-level performance: a review, a proposed model, and new directions for future research", The Academy of Management Annals, Vol. 8, pp. 127-179.

Desmidt, S. and Heene, A. (2003), (Year) Published, "Mission statements: in search for ameliorated performance through organisation-employee value congruence", The First Workshop of the EGPA Study Group on Ethics and Integrity of Governance.

Desmidt, S., Prinzie, A. and Decramer, A. (2011), "Looking for the value of mission statements: a metaanalysis of 20 years of research", Management Decision, Vol. 49, pp. 468-483.

Dumitrascu, M. and Feleaga, L. (2019), "Mission, vision, and values of organizations, the catalysts of corporate social responsibility", Audit Financiar, Vol. 17, pp. 142-148.

Edwards, J.R. and Cable, D.M. (2009), "The value of value congruence”, Journal of Applied Psychology, Vol. 94, pp. 654-677.

Faul, F., Erdfelder, E., Lang, A.-G. and Buchner, A. (2007), "G*Power 3: a flexible statistical power analysis program for the social, behavioral, and biomedical sciences", Behavior Research Methods, Vol. 39, pp. 175-191.

Ford, R.C., Sivo, S.A., Fottler, M.D., Dickson, D., Bradley, K. and Johnson, L. (2006), “Aligning internal organizational factors with a service excellence mission: an exploratory investigation in health care", Health Care Manage Rev, Vol. 31, pp. 259-269.

Gardner, W.L., Reithel, B.J., Foley, R.T., Cogliser, C.C. and Walumbwa, F.O. (2009), "Attraction to organizational culture profiles: effects of realistic recruitment and vertical and horizontal individualism—collectivism”, Management Communication Quarterly, Vol. 22, pp. 437-472.

Gharibvand, S. (2012), "The relationship between Malaysian organizational culture, participative leadership style, and employee job satisfaction among Malaysian employees from semiconductor industry", International Journal of Business and Social Science, Vol. 3, pp. 289-298.

Greenberg, J. and Baron, R.A. (1997), Behavior in Organizations: Understanding and Managing the Human Side of Work, Prentice Hall, Upper Saddle River, New Jerssey, NJ.

Grünig, R. and Kühn, R. (2015), "Stakeholder analysis and revising the mission statement", in Grünig, R. and Kühn, R. (Eds), The Strategy Planning Process, Springer, Berlin.

Hair, J.F., Hult, G.T.M., Ringle, C. and Sarstedt, M. (2017), A Primer on Partial Least Squares Structural Equation Modeling (PLS-SEM), Sage Publications, Los Angeles, LA.

Hair, J.F., Risher, J.J., Sarstedt, M. and Ringle, C.M. (2019), "When to use and how to report the results of PLS-SEM", European Business Review, Vol. 31, pp. 2-24. 
Haque, M.S. (2003), "The role of the state in managing ethnic tensions in Malaysia: a critical discourse", American Behavioral Scientist, Vol. 47, pp. 240-266.

Hashim, M.K. and Zakaria, M. (2013), A Study on Leadership Styles in SMEs.

Henseler, J., Sinkovics, R., R., J.B.J., Daekwan Kim, R., Ringle, C.M. and Sarstedt, M. (2016), “Testing measurement invariance of composites using partial least squares", International Marketing Review, Vol. 33, pp. 405-431.

Hermalin, B.E. (1998), "Toward an economic theory of leadership: leading by example", The American Economic Review, Vol. 88, pp. 1188-1206.

Hirota, S., Kubo, K., Miyajima, H., Hong, P. and Won Park, Y. (2010), "Corporate mission, corporate policies and business outcomes: evidence from Japan”, Management Decision, Vol. 48, pp. 1134-1153.

Hoffman, B.J., Bynum, B.H., Piccolo, R.F. and Sutton, A.W. (2011), "Person-Organization value congruence: how transformational leaders influence work group effectiveness", Academy of Management Journal, Vol. 54, pp. 779-796.

Hung, R.Y.Y. (2006), "Business process management as competitive advantage: a review and empirical study", Total Quality Management and Business Excellence, Vol. 17, pp. 21-40.

Ireland, R.D. and Hirc, M.A. (1992), "Mission statements: importance, challenge, and recommendations for development", Business Horizons, Vol. 35, pp. 34-42.

Jurisch, M.C., Ikas, C., Wolf, P. and Krcmar, H. (2013), "Key differences of private and public sector business process change", e-Service Journal, Vol. 9, pp. 3-27.

Keegan, J. (2011), The Mask of Command: A Study of Generalship, Random House, London.

Koch, B.J., Galaskiewicz, J. and Pierson, A. (2014), “The effect of networks on organizational missions", Nonprofit and Voluntary Sector Quarterly, Vol. 44, pp. 510-538.

Kock, N. (2015), "Common method bias in PLS-SEM: a full collinearity assessment approach", International Journal of e-Collaboration (ijec), Vol. 11, pp. 1-10.

Kotter, J.P. and Heskett, J.L. (2008), Corporate Culture and Performance, Simon and Schuster, New York. Kouzes, J.M. and Posner, B.Z. (2006), The Leadership Challenge, John Wiley \& Sons, San Francisco.

Lahey, T. and Nelson, W. (2020), "A dashboard to improve the alignment of healthcare organization decisionmaking to core values and mission statement", Cambridge Quarterly of Healthcare Ethics, Vol. 29, pp. 156-162.

Lin, Y.H. (2012), "Knowledge brokering for transference to the pilot's safety behavior", Management Decision, Vol. 50, pp. 1326-1338.

Mahmoud, A.B., Grigoriou, N., Fuxman, L., Reisel, W.D., Hack-Polay, D. and Mohr, I. (2020), “A generational study of employees' customer orientation: a motivational viewpoint in pandemic time”, Journal of Strategic Marketing, pp. 1-18.

Mahmoud, A.B., Ball, J., Rubin, D., Fuxman, L., Mohr, I., Hack-Polay, D., Grigoriou, N. and Wakibi, A. (2021a), "Pandemic pains to Instagram gains! COVID-19 perceptions effects on behaviours towards fashion brands on Instagram in Sub-Saharan Africa: tech-native vs non-native generations", Journal of Marketing Communications, pp. 1-25.

Mahmoud, A.B., Hack-Polay, D., Grigoriou, N., Mohr, I. and Fuxman, L. (2021b), "A generational investigation and sentiment and emotion analyses of female fashion brand users on Instagram in Sub-Saharan Africa", Journal of Brand Management, Vol. 28, pp. 526-544.

Mahmoud, A.B., Reisel, W.D., Fuxman, L. and Mohr, I. (2021c), "A motivational standpoint of job insecurity effects on organizational citizenship behaviors: a generational study", Scand Journal of Psychology, Vol. 62, pp. 267-275.

Maitlis, S. (2005), "The social processes of organizational sensemaking", The Academy of Management Journal, Vol. 48, pp. 21-49.

Marshall, S.J. (2018), "Strategic planning as sense-making", in Marshall, S.J. (Ed.), Shaping the University of the Future, Springer, Singapore.
Enhanced employee performance levels

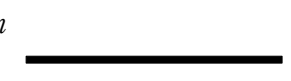


Maxwell, J.C. (2007), The 21 Irrefutable Laws of Leadership: Follow Them and People Will Follow You, HarperCollins Leadership.

Meglino, B.M., Ravlin, E.C. and Adkins, C.L. (1989), "A work values approach to corporate culture: a field test of the value congruence process and its relationship to individual outcomes", Journal of Applied Psychology, Vol. 74, pp. 424-432.

Minai, M.S., Ibrahim, Y. and Kheng, L.K. (2012), "Entrepreneurial network in Malaysia: are there any differences across ethnic groups", Journal of Business and Policy Research, Vol. 7, pp. 178-192.

Mohd Sam, M.F., Tahir, M.N.H. and Abu Bakar, K. (2012), "Owner-managers of SMEs in IT sector: leadership and company performance", International Journal of Business and Social Science, Vol. 3, pp. 195-205.

Mullane John, V. (2002), "The mission statement is a strategic tool: when used properly", Management Decision, Vol. 40, pp. 448-455.

Nowlin, B.M. (2009), The Influence of Mission Statements on Select Aspects of Organizational Decision Making by Executive Directors of California State University Nonprofit Charitable Foundations, Doctor of Education, Pepperdine University.

O'reilly, C.A. and Chatman, J. (1986), "Organizational commitment and psychological attachment: the effects of compliance, identification, and internalization on prosocial behavior", Journal of Applied Psychology, Vol. 71, pp. 492-499.

O'reilly, C.A. and Chatman, J.A. (1996), "Culture as social control: corporations, cults, and commitment", Research in Organizational Behavior: an Annual Series of Analytical Essays and Critical Reviews, Elsevier Science/JAI Press, Vol. 18.

O'reilly, C.A., Chatman, J. and Caldwell, D.F. (1991), "People and organizational culture: a profile comparison approach to assessing person-organization fit", Academy of Management Journal, Vol. 34, pp. 487-516.

Patel, B.S., Booker, L.D., Ramos, H.M. and Bart, C. (2015), "Mission statements and performance in non-profit organisations", Corporate Governance, Vol. 15, pp. 759-774.

Pearce, J.A. and David, F. (1987), "Corporate mission statements: the bottom line", Academy of Management Perspectives, Vol. 1, pp. 109-115.

Posner, B.Z. (2010), "Another look at the impact of personal and organizational values congruency", Journal of Business Ethics, Vol. 97, pp. 535-541.

Posner, B.Z., Kouzes, J.M. and Schmidt, W.H. (1985), "Shared values make a difference: an empirical test of corporate culture”, Human Resource Management, Vol. 24, pp. 293-309.

Ralph, I.W.J., Daniel, L.M. and John, V.M. (2014), "Reinvigorating the mission statement through top management commitment", Management Decision, Vol. 52, pp. 446-459.

Rigby, D. and Bilodeau, B. (2011), Management Tools and Trends 2013, Bain \& Company, London.

Ringle, C.M., Sarstedt, M., Mitchell, R. and Gudergan, S.P. (2020), "Partial least squares structural equation modeling in HRM research", The International Journal of Human Resource Management, Vol. 31, pp. 1617-1643.

Rolls, K., Kowal, D., Elliott, D. and Burrell, A.R. (2008), "Building a statewide knowledge network for clinicians in intensive care units: knowledge brokering and the NSW intensive care coordination and monitoring unit (ICCMU)", Australian Critical Care, Vol. 21, pp. 29-37.

Rupprecht, E.A., Waldrop, J.S. and Grawitch, M.J. (2013), "Initial validation of a new measure of leadership", Consulting Psychology Journal: Practice and Research, Vol. 65, pp. 128-148.

Salehi-Kordabadi, S., Karimi, S. and Qorbani-Azar, M. (2020), "The relationship between mission statement and firms' performance", International Journal of Advanced Studies in Humanities and Social Science, Vol. 9, pp. 21-36.

Sardana, D., Terziovski, M. and Gupta, N. (2016), "The impact of strategic alignment and responsiveness to market on manufacturing firm's performance", International Journal of Production Economics, Vol. 177, pp. 131-138. 
Sattari, S., Pitt Leyland, F. and Caruana, A. (2011), "How readable are mission statements? An exploratory study", Corporate Communications: An International Journal, Vol. 16, pp. 282-292.

Schein, E.H. (2010), Organizational Culture and Leadership, John Wiley \& Sons, San Francisco.

Schroeder, R.G., Anderson, J.C. and Cleveland, G. (1986), "The content of manufacturing strategy: an empirical study", Journal of Operations Management, Vol. 6, pp. 405-415.

Seeber, M., Barberio, V., Huisman, J. and Mampaey, J. (2019), "Factors affecting the content of universities' mission statements: an analysis of the United Kingdom higher education system", Studies in Higher Education, Vol. 44, pp. 230-244.

Senge, P.M. (1997), “The fifth discipline”, Measuring Business Excellence, Vol. 1, pp. 46-51.

Shmueli, G., Sarstedt, M., Hair, J.F., Cheah, J.H., Ting, H., Vaithilingam, S. and Ringle, C.M. (2019), "Predictive model assessment in PLS-SEM: guidelines for using PLSpredict", European Journal of Marketing, Vol. 53, pp. 2322-2347.

Spector, P.E. (2019), "Do not cross me: optimizing the use of cross-sectional designs", Journal of Business and Psychology, Vol. 34, pp. 125-137.

Stallworth Williams, L. (2008), "The mission statement: a corporate reporting tool with a past, present, and future", The Journal of Business Communication (1973), Vol. 45, pp. 94-119.

Swales, J.M. and Rogers, P.S. (1995), "Discourse and the projection of corporate culture: the mission statement", Discourse and Society, Vol. 6, pp. 223-242.

Tahir, H.M., Razak, N.A. and Rentah, F. (2018), "The contributions of small and medium enterprises (SME's) on Malaysian economic growth: a sectoral analysis", in Lokman, A.M., Yamanaka, T., Lévy, P., Chen, K. and Koyama, S. (Eds), Proceedings of the 7th International Conference on Kansei Engineering and Emotion Research 2018. KEER 2018. Advances in Intelligent Systems and Computing, Springer, Singapore.

Tehseen, S., Ramayah, T. and Sajilan, S. (2017), "Testing and controlling for common method variance: a review of available methods", Journal of Management Sciences, Vol. 4, pp. 142-168.

Thiry, M. (2001), "Sensemaking in value management practice", International Journal of Project Management, Vol. 19, pp. 71-77.

Toh, S.Y. and Koon, V.Y. (2017), "Determining mission statement effectiveness from a fit perspective", Studies in Business and Economics, Vol. 12, pp. 220-240.

Webpower (2015), "Univariate and multivariate skewness and kurtosis calculation”, [Online]. available at: https://webpower.psychstat.org/models/kurtosis/ (accessed 02 December 2018).

Weiss, J.A. and Piderit, S.K. (1999), "The value of mission statements in public agencies”, Journal of Public Administration Research and Theory, Vol. 9, pp. 193-224.

Yilmaz, C. and Ergun, E. (2008), "Organizational culture and firm effectiveness: an examination of relative effects of culture traits and the balanced culture hypothesis in an emerging economy", Journal of World Business, Vol. 43, pp. 290-306.

Yukl, G. (2012), "Effective leadership behavior: what we know and what questions need more attention", The Academy of Management Perspectives, Vol. 26, pp. 66-85.

\section{Corresponding author}

Ali B. Mahmoud can be contacted at: elguitarrista@live.com

For instructions on how to order reprints of this article, please visit our website:

www.emeraldgrouppublishing.com/licensing/reprints.htm

Or contact us for further details: permissions@emeraldinsight.com
Enhanced

employee

performance

levels 